\title{
KEBIASAAN MAKAN MAKANAN TINGGI PURIN DENGAN KADAR ASAM URAT DI PUSKESMAS
}

\author{
Veronica Flaurensia Magdalena Kussoy \\ Rina Kundre \\ Ferdinand Wowiling
}

\author{
Program Studi Ilmu Keperawatan Fakultas Kedokteran \\ Universitas Sam Ratulangi \\ Email : veronicakussoy@gmail.com
}

\begin{abstract}
Unhealthy community eating patterns by consuming high protein foods that contain high purine levels causes the incidence of hyperuricemia to increase. Consuming high purine foods will increase uric acid levels in the blood, which predisposes to gouty arthritis. The aim was to determine the Corelation between high purine food eating habits with uric acid levels in the working area of Remboken Community Health Center. The research design used descriptive analytic with Cross Sectional Study approach. A sample of 51 respondents was obtained using the Total Sampling technique. The results of statistical test studies using the Fisher's Exact Test at a significance level of 95\%, obtained a significant value $\rho=0.034<\alpha$ (0.05). The conclusion is that there is a relationship between eating habits of high purine foods with uric acid levels.
\end{abstract}

Keywords : Purines, Gout, Eating habits

\begin{abstract}
Abstrak : Pola makan masyarakat yang tidak sehat dengan mengkonsumsi makanan berprotein tinggi yang mengandung kadar purin tinggi menyebabkan kejadian hiperurisemia semakin meningkat. Mengkonsumsi makanan tinggi purin akan meningkatkan kadar asam urat dalam darah, yang merupakan predisposisi terjadinya gout arthritis. Tujuan untuk mengetahui hubungan kebiasaan makan makanan tinggi purin dengan kadar asam urat di wilayah kerja puskesmas remboken. Desain penelitian yang digunakan yaitu Deskriptif Analitik dengan pendekatan Cross Sectional Study. Sampel berjumlah 51 responden yang didapat dengan menggunakan tehnik Total Sampling. Hasil penelitian uji statistik menggunakan uji Fisher's Exact Test pada tingkat kemaknaan 95\%, didapatkan nilai signifikan $\rho=0,034<\alpha(0,05)$. Kesimpulan ada hubungan antara kebiasaan makan makanan tinggi purin dengan kadar asam urat.
\end{abstract}

Kata kunci : Purin, Asam Urat, Kebiasaan makan

\section{PENDAHULUAN}

Gout atau sering disebut dengan asam urat merupakan hasil metabolisme di dalam tubuh, yang kadarnya tidak boleh berlebih. Setiap orang memiliki asam urat di dalam tubuh, karena pada setiap metabolisme normal dihasilkan asam urat. Asam urat merupakan hasil metabolisme akhir dari purin yaitu salah satu komponen asam nukleat yang terdapat dalam inti sel tubuh (Andri \&Yudha, 2017).
Menurut WHO asam urat adalah bagian dari metabolisme purin, namun apabila tidak berlangsung secara normal maka akan terjadi sebuah proses penumpukan kristal dari asam urat pada persendian yang bisa mengakibatkan rasa sakit yang cukup tinggi. Asam urat sudah ada pada tubuh kita dan bukan suatu penyakit, asal asam urat tersebut dalam nilai yang normal. Pada keadaan normal kadar asam urat serum pada laki-laki mulai meningkat setelah pubertas. Pada 
perempuan kadar asam urat tidak meningkat sampai setelah menopause karena estrogen meningkatkan ekskresi asam urat melalui ginjal. Setelah menopause, kadar urat serum meningkat seperti pada pria (Fajarina, 2011).

Kadar asam urat tinggi atau hiperurisemia merupakan keadaan terjadinya peningkatan kadar asam urat di atas normal dan juga merupakan suatu keadaan dimana konstentrasi monosodium berlebih dalam kelarutannya, dan lebih banyak menyerang pria dari pada wanita (Andri \& Yudha, 2017). Peningkatan kadar asam urat dapat mengakibatkan gangguan pada tubuh manusia seperti perasaan linulinu di daerah persendian dan sering disertai timbulnya rasa nyeri yang teramat sangat bagi penderitannya Andry (2009). Prevalensi hiperurisemia berbeda-beda pada setiap golongan umur dan meningkat pada usia 30 tahun pada pria dan usia 50 tahun pada wanita.

Hiperurisemia di Manado dan Minahasa termasuk tinggi dibandigkan dengan daerah lain di Indonesia karena kebiasaan makan ikan dan mengkonsumsi alkohol. Angka kejadian hiperurisemia pada tahun 1999 sebesar 34,30\% pada pria dan $23,31 \%$ pada wanita usia dewasa muda. Hal tersebut berhubungan dengan kondisi pria yang mempunyai kadar asam urat yang lebih tinggi dari pada perempuan, dan perempuan mempunyai hormon esterogen yang ikut membuang asam urat melalui urin dan juga ikut terbuang bersamaan dengan darah haid melalui siklus menstruasi (Ningsih, 2013).

Pola makan masyarakat yang tidak sehat dengan mengkonsumsi makanan berprotein tinggi, terutama protein hewani yang mengandung kadar purin tinggi menyebabkan kejadian hiperurisemia semakin meningkat. Mengkonsumsi makanan tinggi purin akan meningkatkan kadar asam urat dalam darah, yang merupakan predisposisi terjadinya gout arthritis dan batu ginjal. Kandungan purin yang tinggi terutama terdapat dalam jeroan, kerang, kepiting, dan ikan teri.
Asupan purin merupakan faktor risiko paling kuat yang berhubungan dengan kejadian hiperurisemia (Ningsih, 2014).

Kebiasaan makan adalah faktor penting yang berpengaruh kepada status kesehatan dan kemampuan fisik seseorang. Banyaknya makanan tinggi purin yang dikonsumsi akan semakin memperbesar risiko terkena asam urat. Risiko terjadinya asam urat akan bertambah bila disertai dengan pola konsumsi makan yang tidak seimbang. Ada berbagai faktor yang dapat meyebabkan kelebihan asam urat di dalam darah, tetapi asupan purin mempunyai pengaruh paling besar (Fajarina, 2011).

Survei pendahualuan pengambilan data awal pada bulan Juni 2019 di Puskesmas Kecamatan Remboken, didapat jumlah total pasien yang telah melakukan pemeriksaan sebelumnya pada tiga bulan terakhir yaitu pada bulan Maret sampai dengan Mei adalah berjumlah 51 pasien. Dari uraian-uraian diatas, maka peneliti tertarik melakukan analisa tentang "Hubungan Kebiasaan Makan Makanan Tinggi Purin Dengan Kadar Asam Urat"

\section{METODE PENELITIAN}

Penelitian ini termasuk dalam jenis penelitian kuantitatif dengan menganalisis gambaran perbedaan antara kedua variabel yaitu variabel independen (Kebiasaan Makan Tinggi Purin) dan variabel dependen (Kadar Asam Urat). Penelitian ini menggunakan jenis penelitian Observasional analitik, dengan pendekatan cross sectional study. Penelitian ini dilaksanakan di Puskesmas Remboken pada bulan Mei 2018-Juli 2019. Populasi pada penelitian ini adalah masyarakat yang melakukan pemeriksaan asam urat di Puskesmas Kecamatan Remboken. Berdasarkan data yang diperoleh, jumlah masyarakat yang telah melakukan pemeriksaan asam urat pada bulan maret hingga bulan mei 2019 berjumlah 51 orang. Teknik pengambilan sampel dalam penelitian ini menggunakan metode Total Sampling dengan total 51 orang. Instrumen penelitian yang digunakan untuk mengukur 
variabel Kebiasan Makan Makanan Tinggi Purin metode Food Frequency Questionnaire (FFQ) (Hardiansyah, 2014) dan pada variabel asam urat menggunakan metode Standar Operasional Prosedur (SOP) (Sucipto, 2014) dengan menggunakan pengukur kadar asam urat digital yang terdiri dari autocheck, stick asam urat, jarum lancet, alcohol swab. Dengan Kriteria objektif Kadar asam urat tinggi $>7$ pada pria dan $>5$ pada wanita, dan terkontrol $<7$ pada pria dan $<5$ pada wanita.

Pengolahan data yang diperoleh dari hasil penelitian ini diolah secara manual dengan mengelompokkan hasil observasi kemudian dilakukan penghitungan skor dan dianalisis menggunakan uji statistik melalui sistem komuterisasi dengan beberapa tahap yaitu editing, coding, cleaning, tabulating (Notoatmodjo, 2010). Analisa bivariat dalam penelitian ini yaitu untuk mengetahui Hubungan Kebiasaan Makan Makanan Tinggi Purin Dengan Kadar Asam Urat. Peneliti menggunakan uji statistic Chi-square dengan tingkat kemaknaan $95 \%(\alpha=0,05)$.

\section{HASIL dan PEMBAHASAN}

\section{Karakteristik Responden}

Tabel 1. Distribusi Responden Berdasarkan Jenis Kelamin

\begin{tabular}{ccc}
\hline Jenis Kelamin & n & \% \\
\hline Laki-laki & 22 & 43,1 \\
Perempuan & 29 & 56,9 \\
\hline Total & $\mathbf{5 1}$ & $\mathbf{1 0 0}$ \\
\hline
\end{tabular}

Berdasarkan hasil penelitian pada 51 responden didapatkan bahwa mayoritas responden adalah berjenis kelamin perempuan sebanyak 29 responden (56,9\%) sedangkan laki-laki sebanyak 22 responden $(43,1 \%)$. Penelitian ini sejalan dengan penelitian yang dilakukan oleh Husnah dan Chamayasinta (2013) yang berjudul hubungan pengetahuan diet purin dengan kadar asam urat pasien gout arthritis dengan jumlah sampel 52 responden dengan mayoritas berjenis kelamin perempuan yaitu sebanyak 29 responden $(55,8 \%)$, sedangkan responden dengan jenis kelamin laki-laki sebanyak 23 responden $(44,2 \%)$.

Tabel 2. Distribusi Responden Berdasarkan Usia

\begin{tabular}{ccc}
\hline Usia & $\mathbf{n}$ & $\mathbf{\%}$ \\
\hline 35-40 Tahun & 3 & 5,9 \\
41-50 Tahun & 13 & 25,5 \\
51-60 Tahun & 17 & 33,3 \\
>60 Tahun & 18 & 35,3 \\
\hline Total & $\mathbf{5 1}$ & $\mathbf{1 0 0}$ \\
\hline
\end{tabular}

Hasil penelitian yang dilakukan pada 51 responden di dapatkan mayoritas responden berusia > 60 tahun yaitu sebanyak 18 orang (35,3\%), 51-60 tahun sebanyak 17 orang $(33,3 \%), 41-50$ tahun sebanyak 13 orang $(25,5 \%)$ dan rentang usia paling sedikit yaitu 35-40 tahun sebanyak 3 orang $(5,9 \%)$. Hasil penelitian ini sejalan dengan penelitian yang dilakukan oleh Untari \& Wijayanti (2017) dengan judul hubungan antara pola makan dengan penyakit gout didapatkan usia responden mayoritas berusia > 60 tahun

\section{Analisa Univariat}

Tabel 3. Distribusi dan Presentase Kebiasaan Makan Tinggi Purin

\begin{tabular}{ccc}
\hline Kategori & $\mathbf{n}$ & $\mathbf{\%}$ \\
\hline Sering & 29 & 56,9 \\
Jarang & 22 & 43,1 \\
\hline Total & $\mathbf{5 1}$ & $\mathbf{1 0 0}$ \\
\hline
\end{tabular}

Tabel 3 menunjukan hasil penelitian yang dilakukan di Puskesmas Remboken dengan jumlah responden 51 orang, sebanyak 29 responden $(56,9 \%)$ memiliki kebiasaan makan tinggi purin yang sering. Sedangkan 22 responden $(43,1 \%)$ dalam kategori jarang. Hal ini menandakan bahwa kebiasaan makan makanan tinggi purin di puskesmas remboken dalam keadaan yang sering makan makanan tinggi purin yaitu dibuktikan dengan jawaban kuesioner para responden sering makan makanan seperti daging ayam, daging babi, ikan mujair, kacang kacangan serta sayur buncis 
sebanyak hampir 3 kali per minggu. Hal ini sejalan dengan penelitian Silviana, dkk, (2014) yang berjudul Hubungan Status Gizi, Asupan Bahan Makan Sumber Purin dengan Kadar Asam Urat pada Pasien Hiperuresemia Rawat Jalan di Rumah Sakit Tugurejo Semarang dengan jumlah semua responden $22(100,0 \%)$ orang dalam kategori sering makan makanan tinggi purin.

Hasil persentase penelitian di Puskesmas Remboken menunjukkan kebiasaan makan tinggi purin sebanyak 29 $(56,9 \%)$ responden memiliki kebaisaan mengkonsumsi makanan tinggi purin yang sering. Teori menyatakan bahwa kebiasaan mengkonsumsi makan makanan tinggi purin yang sering dapat meningkatkan kadar asam urat dalam darah (Diantari, 2012). Menurut Silviana, dkk, (2014) asam purin yang terkandung dalam makanan akan diubah menjadi asam urat. Purin adalah salah satu senyawa basa organik yang menyusun asam nukleat atau inti dari sel yang termasuk dalam kelompok asam amino, unsur pembentuk protein. Konsumsi makanan tinggi purin memicu tingginya kadar asam urat didalam serum, contoh makanan kaya purin yaitu makanan laut, jeoran, dan kacang-kacangan (Nursilmi, 2014).

Kebiasaan konsumsi makan makanan yang kaya purin dalam penelitian ini tidak diukur berapa jumlah (gram) dalam sehari, akan tetapi pada saat wawancara dan mengisi kuesioner peneliti lebih menekankan kepada apakah pasien memiliki kebiasaan konsumsi makanan tersebut. Pasien dalam penelitian ini yang memiliki kebiasaan konsumsi makan makanan tinggi purin tidak melakukan kontrol batasan maksimum untuk mengonsumsinya.
Tabel 4. Distribusi dan Presentase Kadar Asam Urat

\begin{tabular}{ccc}
\hline Kategori & $\mathbf{n}$ & $\mathbf{\%}$ \\
\hline Tinggi & 44 & 86,3 \\
Terkontrol & 7 & 13,7 \\
\hline Total & $\mathbf{5 1}$ & $\mathbf{1 0 0}$ \\
\hline
\end{tabular}

Berdasarkan hasil penelitian yang dilakukan di Puskesmas Remboken dengan jumlah responden 51 orang, sebanyak 44 responden $(86,3 \%)$ memiliki kadar asam urat dalam kategori tinggi. Hal ini menandakan bahwa kadar asam urat di Wilayah Kerja Puskesmas Remboken masih banyak yang memiliki kadar asam urat yang tinggi. Hal ini sejalan dengan penelitian Silviana, dkk, (2014) yang berjudul Hubungan Status Gizi, Asupan Bahan Makan Sumber Purin dengan Kadar Asam Urat pada Pasien Hiperuresemia Rawat Jalan di Rumah Sakit Tugurejo Semarang dengan jumlah $16 \quad(72,7 \%)$ responden dalam kategori kadar asam urat yang tinggi/lebih, sedangkan $6(27,3 \%)$ responden dalam kategori normal.

Hasil penelitian menunjukan bahwa mayoritas responden di Puskesmas Remboken memiliki Kadar Asam Urat yang tinggi sebanyak $44 \quad(86,3 \%)$ responden di karenakan banyak mengkonsumsi makanan yang tinggi purin. Setiap orang memiliki asam urat di dalam tubuh karena pada setiap metabolisme normal dihasilkan asam urat. Asam urat yang terdapat dalam tubuh kita tentu saja kadarnya tidak boleh berlebihan. Asam urat dapat berlebih disebabkan adanya pemicu, yaitu makanan dan senyawa lain yang banyak mengandung purin. Sesungguhnya tubuh menyediakan $85 \%$ senyawa purin untuk kebutuhan setiap hari, hal ini berarti bahwa kebutuhan purin dari makanan hanya sekitar 15\% (Artinawati, 2014).

Akibat dari asupan makanan yang tinggi purin oleh para responden sehingga terjadi kenaikan kadar asam urat di dalam tubuh para. Kusumayanti, dkk, (2015) menyebutkan bahwa kenaikan kadar asam urat disebabkan tubuh kekurangan enzim 
urikinase untuk mengubah asam urat sebagai produk akhir metabolisme purin menjadi allantoin larut air, sehingga berbagai penelitian menyebutkan bahwa terdapat hubungan asupan purin dengan kadar asam urat.

Penelitian ini juga didapatkan ada responden yang memiliki kadar asam urat terkontrol sebanyak 7 responden $(13,7 \%)$ yang dikarenakan para responden sering malaksanakan diet purin pada saat peneliti melaksanakan penelitian. Selain hal itu, asam urat yang terkontrol juga dikarenakan faktor usia yang berdasarkan dengan hasil penelitian, kebanyakan dari responden merupakan lanjut usia. Di mana lansia merupakan usia yang rentan terserang penyakit asam urat sehingga kadar asam urat di dalam tubuh bisa terkontrol dan kadang juga bisa tidak terkontrol di karenakan faktor risiko dari penyakit asam urat (Silviana, dkk, 2014).

\section{Analisa Bivariat}

Tabel 5. Hubungan Kebiasaan Makan Tinggi Purin Dengan Kadar Asam Urat Di Wilayah Kerja Puskesmas Remboken

\begin{tabular}{|c|c|c|c|c|c|c|c|}
\hline \multirow{3}{*}{$\begin{array}{c}\text { Kebia } \\
\text { saan } \\
\text { Maka } \\
\text { n } \\
\text { Tinggi } \\
\text { Purin }\end{array}$} & \multicolumn{4}{|c|}{ Kadar Asam Urat } & \multicolumn{2}{|c|}{ Total } & \multirow[t]{3}{*}{$\mathbf{P}$} \\
\hline & \multicolumn{2}{|c|}{ Tinggi } & \multicolumn{2}{|c|}{$\begin{array}{c}\text { Terkontr } \\
\text { ol }\end{array}$} & \multirow[b]{2}{*}{$\mathrm{n}$} & \multirow[b]{2}{*}{$\%$} & \\
\hline & $\mathrm{n}$ & $\%$ & $\mathrm{n}$ & $\%$ & & & \\
\hline Sering & 28 & 96,6 & 1 & 3,4 & 29 & 100 & \\
\hline Jarang & 16 & 72,7 & 6 & 27,3 & 22 & 100 & \\
\hline Total & 44 & 86,3 & 7 & 13,7 & 51 & 100 & \\
\hline
\end{tabular}

Berdasarkan hasil penelitian terhadap 51 responden didapatkan hasil hubungan antara kebiasaan makan tinggi purin dengan kadar asam urat yang tinggi karena kebiasaan sering makan makanan yang tinggi purin sebanyak 28 responden $(96,6 \%)$. Dengan hasil uji statistik diperoleh nilai $\rho=0,034$ maka dapat disimpulkan bahwa ada hubungan antara kebiasaan makan tinggi purin dengan kadar asam urat. Hal ini menandakan bahwa kebiasaan makan tinggi purin di puskesmas remboken dalam keadaan kurang baik karena sering makan makanan tinggi purin yaitu dibuktikan dengan jawaban kuesioner para responden sering makan makanan seperti daging ayam, daging babi, ikan mujair, kacang kacangan serta sayur buncis sebanyak hampir 3 kali per minggu. Hasil penelitian ini sejalan dengan penelitian yang dilakukan oleh Silviana, dkk, (2014) yang berjudul Hubungan Status Gizi, Asupan Bahan Makan Sumber Purin dengan Kadar Asam Urat, didapatkan hubungan antara hubungan antara asupan purin dengan kadar asam urat pada pasien.

Penelitian ini juga didapatkan ada responden yang memiliki kadar asam urat terkontrol sebanyak 1 orang $(3,4 \%)$ tetapi sering makan makanan tinggi purin dan ada juga yang memiliki kadar asam urat yang tinggi sebanyak 16 orang $(72,7 \%)$ tetapi jarang mengkonsumsi makanan yang tinggi purin. Hal ini disebabkan karena berdasarkan dengan hasil penelitian, kebanyakan dari responden merupakan lanjut usia. Di mana lansia merupakan usia yang rentan terserang penyakit asam urat sehingga kadar asam urat di dalam tubuh bisa terkontrol dan kadang juga bisa tidak terkontrol dikarenakan faktor risiko dari penyakit asam urat (Silviana, dkk, 2014). Hal yang menyebabkan responden memiliki kadar asam urat yang tinggi tetapi jarang mengkonsumsi makanan tinggi purin dikarenakan kadar asam urat yang tinggi tidak hanya disebabkan oleh makanan tinggi purin akan tetapi banyak faktor risiko yang lain seperti faktor keturunan atau riwayat kesehatan keluarga, berat badan yang berlebihan, dan tidak menerapkan pola hidup yang sehat (Silviana, dkk, 2014).

Hasil penelitian ini juga didapatkan 6 responden $(27,3 \%)$ memiliki kadar asam urat terkontrol dikarenakan kebiasaan makan tinggi purin yang jarang. Penelitian ini dibuktikan dari beberapa jawaban kuesioner dari responden ada yang menjawab jarang makan makanan yang mengandung tinggi purin seperti jeroan, seafood, dan kacang-kacangan 
dengan presentasi 1 kali dalam sebulan. Tinggi rendahnya asam urat seseorang tergantung dari apa yang dikonsumsi dan pola hidup yang tidak sehat, sehingga seseorang yang mengalami asam urat dapat disebabkan oleh beberapa faktor salah satunya adalah makanan yang di konsumsinya (Utami, 2009).

Peningkatan kadar asam urat dengan cepat dapat terjadi, antara lain karena asupan makanan yang tinggi purin. Dalam kehidupan sehari-hari, pembatasan konsumsi makanan tinggi purin, seperti daging, jeroan, dan berbagai jenis sayuran dan kacang-kacangan yang mengandung purin perlu dilakukan, teutama bagi penderita kadar asam urat tinggi, karena hal ini berpeluang meningkatkan metabolisme purin didalam tubuh yang menghasilkan kadar asam urat berlebih didalam darah. Hal ini dikarenakan tubuh telah menyediakan $85 \%$ senyawa purin untuk kebutuhan tubuh, sedangkan dari makanan hanya diperlukan $15 \%$ saja (Indriawan, 2009).

Hasil Penelitian ini juga menunjukkan besarnya pengaruh asupan purin terhadap kadar asam urat pada responden yang diteliti. Jadi semakin tinggi asupan purin maka akan semakin tinggi pula kadar asam urat. Selain itu, Astuti dan Tjahjono (2014) juga menyebutkan bahwa terdapat pengaruh faktor diet tinggi purin terhadap kadar asam urat (gout). Hasil penelitian ini juga sesuai dengan hasil penelitian Diantari (2012) yang menunjukkan bahwa ada pengaruh positif asupan purin dengan kadar asam urat $(\mathrm{p}<0,05)$.

Purin merupakan satu senyawa dimetabolisme di dalam tubuh dan menghasilkan produk akhir yaitu asam urat (Suiraoka, 2012). Sehingga jika terjadi peningkatan sintesa purin dalam tubuh akan mengakibatkan terjadi penumpukan kristal pada asam urat di dalam ruang sendi dimana semakin sering memakan makanan yang mengandung purin tinggi maka semakin tinggi nilai asam urat sehingga keseimbangan asam urat yang ada dalam darah terganggu yang menyebabkan terjadinya peningkatan kadar asam urat (Annita \& Handayani, 2017).

\section{SIMPULAN}

Kebiasaan makan makanan tinggi purin pada masayrakat di wilayah kerja puskesmas remboken adalah sering, sehingga kadar asam urat masyarakat yang ada di wilayah kerja puskesmas remboken tinggi.

\section{DAFTAR PUSTAKA}

Andry. (2009). Analisis faktor-faktor yang mempengaruhi kadara asam urat pada pekerja kantor. Vol 3 Hal 5253

Andry dan Yudha. (2017). Distribusi faktor hiperurisemia terhadap pasien gout arthritis di poliklinik penyakit dalam dan radiologi RSUD Meuraxa Banda Aceh. Vol 6 Hal 64

Annita dan Handayani. (2017). Hubungan Diet Purin Dengan Kadar Asam Urta Pada Penderita Gout Arthritis. STIKES Syedza Saintika. Vol $6 \mathrm{Hal}$ 106

Artinawati, S. (2014). Asuhan Keperawatan Gerontik. Jakarta : In Media. Hal 52

Astuti., dan Tjahjono. (2014). FaktorFaktor Yang Mempengaruhi Kadar Asam Urat (Gout) Pada Laki-Laki Dewasa. Jurnal Portal Garuda. Vol 5 Hal 99-100

Diantari, E. (2012). Pengaruh Asupan Purin Dan Cairan Terhadap Kadar Asam Urat Pada Wanita Usia 50-60 Tahun. Fakultas Kedokteran universitas Diponegoro. Vol $4 \mathrm{Hal}$ 74

Fajarina, E. (2011). Analisa Pola Konsumsi Dan Pola Aktivitas 
Dengan Kadar Asam Urat Pada Lansia Di Bogor. Vol 4 Hal 43

Hardiansyah, (2014). Ilmu Gizi, Teori dan Aplikasi. Jakarta : EGC Hal 58

Husnah dan Chamayasinta. (2013). Hubungan Pengetahuan Diet Purin Dengan Kadar Asam Urat Pasien Gout Arthritis. Fakultas Kedokteran Universitas Syiah Kuala. Vol 4 Hal 93

Indriawan. (2019). Penyakit Asam urat / Gout. Unikom.ac.id. Vol 7 Hal 69

Kusumayanti, DGA., Wiardani, NK., Antarini, NAA. (2015). Pola Konsumsi Purin Dan Kegemukan Sebagai Faktor Resiko Hiperurisemia Pada Masyarakat Kota Denpasar. Jurnal Skala Husada. Vol 6 Hal 85

Ningsih, S., W. (2014). Gambaran Asupan Purin, Penyakit Arthritis Gout, Di Kecamatan Tumalanrea. Vol $5 \mathrm{Hal}$ 99

Notoadmodjo, S. (2010). Metodologi penelitian kesehatan. Jakarta : Rineka Cipta. Hal 102

Nursilmi. (2013). Hubungan Pola Konsumsi, Status Gizi Dan Aktivitas Fisik Dengan Kadar Asam Urat Lansia Wanita Peserta Posbindu Sinarsari. Fakultas Ekologi Manusia IPB. Vol $4 \mathrm{Hal}$ 115-116

Silviana, H., Bintanah, S., Isworo, J. T. (2014). Hubungan Status Gizi, Asupan Bahan Makan Sumber Purin dengan Kadar Asam Urat pada Pasien Hiperuresemia Rawat Jalan di Rumah Sakit Tugurejo Semarang. Fakultas ilmu Keperawatan Universitas Muhammadiyah Semarang. Vol 5 Hal 99
Sucipto. (2014). Asam Urat dan Penyakit Kronik Lainnya. Jakarta: Agromedia Pustaka. Hal 95-96

Suiraoka. (2012). Mengenal, Mencegah Dan Mengurangi Faktor Risiko 9 Penyakit Degeneratif. Yogyakarta : Nuha medika. Hal 121

Untari, D., Wijayanti, T. (2017). Hubungan Pola makan Dengan Penyakit Gout. Stikes Muhammadiyah Surakarta. Vol 5 Hal 103

Utami, P., dkk. (2009). Solusi Sehat Asam Urat Dan Rematik. Jakarta: Agromedia Pustaka. Vol 3 Hal 73 